\title{
Ritual Marriage Alliances and Consolidation of Power in Middle Egypt during the Middle Kingdom
}

\author{
NaGuib KanaWATi
}

\begin{abstract}
Middle Egypt is the most fertile region in the country and its provincial governors were the richest and most powerful. Intermarriages between members of neighbouring nomarchic families created a strong power base, resulting in most governors gradually representing themselves in such forms and using formulae which are strictly royal. While there is no evidence that any of the governors actually challenged the authority of the king, it seems doubtful if the latter would have been pleased with the grand claims made by some of his top administrators and the royal prerogatives they attributed to themselves. The almost simultaneous end of Middle Kingdom nobility in different provinces, under Senwosret III, even though presumably not everywhere at exactly the same time, appears to have been the result of a planned central policy, although each province was dealt with differently and as the opportunity presented itself.
\end{abstract}

Keywords: Middle Kingdom Egypt, Twelfth Dynasty, provincial administration, marriage and politics, crown and officials, usurpation of power

Naguib Kanawati, Australian Centre for Egyptology, Macquarie University, Sydney; naguib.kanawati@mq.edu.au

According to two studies conducted by the Egyptian Ministry of Agriculture, Middle Egypt, or broadly the area between nomes 9 and 20, is the most fertile and most productive land in the country, ${ }^{1}$ and we have no reason to believe that conditions were different in the Middle Kingdom. The wealth of the region in ancient times may be gauged by the richness of the tombs of its provincial governors, particularly those of Asyut, Meir, el-Bersha and Beni Hassan. The resources of these provinces were so essential to the central government that men of special abilities and trust must have initially been selected to administer them. Yet as time passed these men and/or their descendants were likely to be more established in the provinces they governed and the ties between them and the palace to become weaker as they felt more powerful and secure in their positions.

${ }^{1}$ See: Fisher 1971: 496ff., Fig. 19.6; Kanawati 1980: 6-7, Figs 1-2; Lashien 2015: 122-123, 130-131. 
With the wealth of resources available to them, the nomarchs of the different provinces in this region must have formed elite groups, with common interests and concerns, and for these reasons intermarriages between members of their families must have become the norm. One of the clear examples of this may be found in the biography of Khnumhotep II of Beni Hassan who was appointed by Amenemhat II to the inheritance of his maternal grandfather. Khnumhotep II wrote: My principal nobility was due to my birth. My mother proceeded as a hereditary princess, countess, and as the daughter of the ruler of the Oryx nome, to the domain of Sehotepibre, given life, stability and dominion like Re for ever, to become the wife of the hereditary prince, the count, the ruler of the new towns, whom the king proclaimed as foster child of the king of Lower Egypt, according to his rank of overseer of the city, Nehri. ${ }^{2}$ Khnumhotep II's mother was certainly from the Oryx nome since she was the daughter of its ruler, probably Khnumhotep $\mathrm{I}^{3}$ and her name, Baqet, was typical among both male and female members of the ruling family of the $16^{\text {th }}$ province of Upper Egypt. But who was his father, Nehri? His name was previously unattested at Beni Hassan, nor was his office of jmj-r njwt 'overseer of the city/mayor', ${ }^{4}$ although Khnumhotep II himself was later given this title, ${ }^{5}$ probably through his father. Based on a Khnumhotep II statement that his father made for himself a tomb at Mer-nofret, D.B. Redford presents a reasonable argument that he originated from the $18^{\text {th }}$ nome. ${ }^{6}$ The title jmj-r njwt is rarely associated with that of a particular town, as for example jmj-r njwt $3 b \underline{d} w$, but is occasionally used in the title jmj-r njwt $m r$ 'overseer of the pyramid town', held in the capital by many viziers $t 3 j t j s 3 b t 3 t j .{ }^{7}$ When the name of the town in the title $j m j-r$ njwt is not specified, it may be assumed that it was held at the capital, whether Thebes or el-Lisht. ${ }^{8}$ This may explain Nehri's closeness to the sovereign and his proclamation as 'foster child of the king of Lower Egypt', as well as Khnumhotep II's statement that his mother 'proceeded/went' $w \underline{d} 3$ to the domain of 'Sehotepibre' Shtp-jb-Re in order to marry Nehri. The location of this domain is uncertain, but it might have been close to, or part of

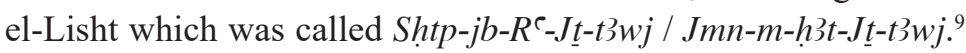

The governor, hrj-tp 3 , of the neighbouring $15^{\text {th }}$ Upper Egyptian nome at the beginning of the Twelfth Dynasty was also called Nehri. He owns a tomb at el-Bersha, unfortunately in a poor state of preservation, ${ }^{10}$ but also a number of graffiti in the quarries of Hatnub from which we know his titles. ${ }^{11}$ In addition to being a nomarch, this nobleman was a vizier,

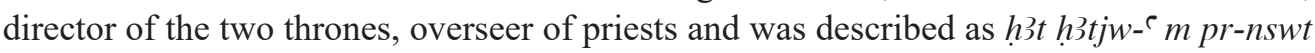

\footnotetext{
2 Newberry 1893: P1. 25; Kanawati, Evans, 2014a: 33, P1. 111.

${ }^{3}$ Favry 2005: 62; Grajetzki 2009: 136.

4 Ward 1982: 31 [220].

${ }^{5}$ It is inscribed only on the entrance to his shrine (Newberry 1893: P1. 33; Kanawati, Evans 2014a: Pl. 134).

${ }^{6}$ Redford 1967: 158-159.

7 Ward 1982: 31.

${ }^{8}$ Agreeing with Nelson-Hurst 2015: 266, who writes that Khnumhotep II likely grew up near the capital, since his father Nehri worked in that area, though he was likely originally from Middle Egypt (perhaps from another provincial ruling family).

9 Ward 1982: 211.

${ }^{10}$ Griffith, Newberry 1893: 29, Pls 10-11.

11 Favry 2005: 32-33.
} 
'foremost of the counts in the palace' and jmj-r njwt 'overseer of the city/mayor'. Nehri even dated events to his years as nomarch rather than to the years of the reigning king and used the royal epithets ${ }^{\top} n h \underline{h} w \underline{d}$ s snb and ' $n h \underline{d} \underline{d} t$. He states in one of the graffiti that he came to Hatnub as a man of 73 years. ${ }^{12}$ Redford however argues that Nehri of el-Bersha could not be the father of Khnumhotep II, since he was the son of Kay, not Sobekankh. ${ }^{13}$ Considering the intermarriages between these noble families, one still wonders if the two Nehris were at least related.

Later in his biography Khnumhotep II says: another favour which was done to me: my eldest son, Nakht, born to Khety, was appointed to be ruler of the Jackal nome, to the inheritance of the father of his mother. ${ }^{14}$ This is a clear indication that Khnumhotep II's

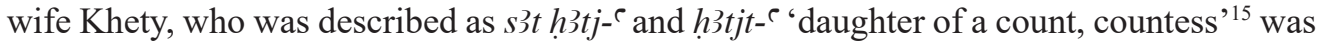
the daughter of the ruler of the neighbouring Jackal nome (no. 17), with the result of more important posts falling into the hands of members of his immediate family. The name of Khnumhotep II's wife, Khety, is the same as that of an earlier governor of the Oryx nome, owner of tomb no. $17 .{ }^{16}$ Whether Khnumhotep II's wife was named after the governor of the Oryx nome, or one of her parents originated from this province is unknown, yet intermarriages between members of the elite families of the $16^{\text {th }}$ and $17^{\text {th }}$ provinces is certain and between those of the $16^{\text {th }}$ and $15^{\text {th }}$ or the $18^{\text {th }}$ provinces seems likely.

The first known Middle Kingdom noble buried at Meir is $S_{n j}{ }^{17}$ 'Senbi (I)' of tomb no. B1. ${ }^{18}$ Nothing is known about his background except that his father was called $W h$ - htp (.w) 'Wekhhotep', ${ }^{19}$ a name which, like many others at el-Qusiya, is formed with the wekh-fetish of Hathor and which became popular among later members of the family. However, since his descendant, Wekhhotep of tomb B4, depicted his ancestors probably going back to the Old Kingdom, it is possible that the noble family of el-Qusiya succeeded in maintaining some kind of authority during the First Intermediate Period, even if the political and economic condition of the country did not enable them to build impressive decorated tombs. Some support of the possibility of Senbi I being of local background is the fact that despite the rarity of his name, a man bearing the same name appears in the tomb of Ppjj- $n h(. w)-h r j-j b$, who inaugurated the cemetery at Meir in the Sixth Dynasty. ${ }^{20}$ Bearing the titles of šps nswt jmj-r pr 'noble of the king, overseer of the house', ${ }^{21}$ this Senbi is one of four individuals accompanying the tomb owner in his spear fishing trip, the others being the latter's wife and two sons. It seems possible that Senbi I, owner of tomb no. B1, was a descendent of the Sixth Dynasty nobility. His main responsibility, like

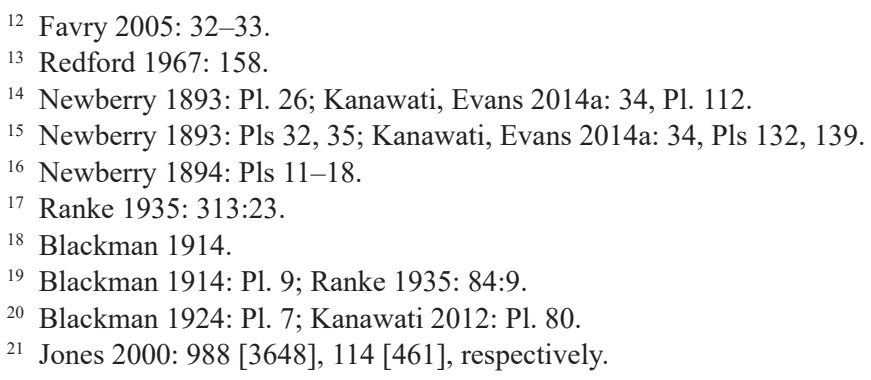


his Sixth Dynasty predecessors, ${ }^{22}$ appears to be that of $j m j-r$ hmww-ntr 'overseer of priests', and he held the high ranks of jrj-p $p^{\top}$ h $3 t j$ - ' hereditary prince and count'. ${ }^{23}$

Senbi I's wife, Mr.s 'Meres', ${ }^{24}$ is represented with him on three occasions; she accompanies him in the spear fishing and fowling trips, where she is described as hmt.f $n$ st-jb.f $n b t j m 3 h$ 'his wife, his favourite, the possessor of honour' 25 and while they receive offerings from offering bearers, where she is designated as jm3hwt pr hmwt Mr.s 'the honoured one of the house of women/wives, Meres'. ${ }^{26}$ This epithet is perhaps similar to that of hnwt hmwt $n b w t$ 'Mistress of all women/wives' held by S3t-jp 'Satip', wife of Khnumhotep I of Beni Hassan, ${ }^{27}$ and both epithets might hint at the presence of many wives, even if only one is represented in the tomb. On the other hand, while Satip was depicted in equal size to her husband, Meres is consistently shown in almost half her husband's size and is not shown with him at the offering table, nor is she allocated a separate table. No earlier attestation of the name Meres is found at el-Qusiya, but the name became popular among women of later generations and it is reasonable to think that even if there were a continuity of government during the First Intermediate Period, both Meres and her husband Senbi (I) must have been considered as the inaugurators of at least a new era for the governing family of el-Qusiya in the Middle Kingdom. But while he was perhaps a descendant of the local nobility, she might have been from elsewhere.

As we have seen in the biography of Khnumhotep II of Beni Hassan, some provincial ruling families seem to have tried to establish a strong power base through marriage alliances with their strong neighbours. Meir (nome 14) and Beni Hassan (nome 16) are not distant from each other ${ }^{28}$ and intermarriages between the children of the nobility of such close provinces should be expected. A daughter of Khnumhotep II and Khety was called Meres ${ }^{29}$ yet the possible dates of Senbi I and Khnumhotep II may make it questionable that the former married the daughter of the latter. Senbi I is estimated to have been in office under Senwosret I, ${ }^{30}$ and Khnumhotep II is known to have been appointed to his top office in the $19^{\text {th }}$ year of Amenemhat II, ${ }^{31}$ but he also may have started his career much earlier. However, marriages of mature aged men in high position with much younger women are well documented in the Old Kingdom. ${ }^{32}$

\footnotetext{
${ }^{22}$ See those buried at both Quseir el-Amarna and Meir (El-Khouli, Kanawati 1989; Blackman 1924; 1953a; Kanawati 2012; Kanawati, Evans 2014b).

${ }^{23}$ Ward 1982: 35 [259], 102 [850], 104 [864]; Jones 2000: 171 [651], 315 [1157], 496 [1858], respectively.

${ }^{24}$ Ranke 1935: 158:5.

25 Blackman 1914: Pl. 2.

${ }_{26}$ Blackman 1914: Pl. 9. Blackman's reading of the name as 'Per-Hemut-meres' 'The Harîm is her lover' (Blackman 1914: 11 n. 3) seems unlikely, and the name is unattested in Ranke's work. This appears to be an epithet for Meres.

${ }_{27}$ Newberry 1893: P1. 46. For the reading of the epithet see: Ward 1982: 115.

${ }_{28}$ See: Helck 1974: 205; Baines, Málek 1980: 121.

29 Newberry 1893: P1. 35; Kanawati, Evans 2014a: P1. 139.

30 See: Favry 2005: 53, 76-77.

31 Newberry 1893: Pl. 25; Kanawati, Evans 2014a: 33, P1. 111.

32 The young daughters of king Teti for example were given in marriage to his much older top officials (see: Kanawati 2003).
} 
It is equally possible that the name Meres was held by an earlier member of Khnumhotep II's family. This noble had three daughters by his wife Khety and one by his likely concubine, and later wife, $\underline{T} 3 t .{ }^{33}$ His daughters were named, apparently in order of age, after earlier generations of women in his family as: B3kt (after his own mother), Tnt (after his mother-in-law, mother of Khety), ${ }^{34} M r . s($ ?), and finally $S 3 t-j p$ (after his likely maternal grandmother, the wife of Khnumhotep I). ${ }^{35}$ Could Meres have been named after Khnumhotep II's possible paternal grandmother, the mother of his distinguished father Nehri? ${ }^{36}$ The possibility that the name Meres was held by both the mother and daughter of Nehri of el-Bersha and that the younger Meres was Senbi's wife should not be excluded. Senbi I might have established marriage alliance with either of his neighbouring provinces, $15^{\text {th }}$ or $16^{\text {th }}$, although relying mainly on names and dates such relationship should remain conjectural.

No children are depicted or named in Senbi I's tomb, ${ }^{37}$ but the owner of the adjacent tomb (B2) is named Wekhhotep (I) son of Senbi and is most probably the son of the owner of tomb B1. Not only did this Wekhhotep (I) hold, among other titles, the ranks of jrj-p't ḩ3tj-` 'hereditary prince and count' and the office of jmj-r hmww-ntr 'overseer of priests', as did other members of this noble family, but he was the only one among them who occupied the position of hrj-tp $3 n$ N ${ }_{\text {dfjt }}$ 'great overlord/nomarch of the $N \underline{d} j j t$-nome', ${ }^{38}$ and it is uncertain whether his responsibilities were restricted to nome 14 or they included both nomes 13 and $14 .{ }^{39}$ This office was occupied at el-Qusiya only once before by the eldest son of Pepyankh the Black ${ }^{40}$ at the end of the Sixth Dynasty or immediately following and was perhaps a response by the central government to certain emerging problems in the vicinity of el-Qusiya. ${ }^{41}$ Wekhhotep I son of Senbi I is probably to be dated to the reign of Senwosret $I{ }^{42}$ a time which was also not without internal problems, ${ }^{43}$ and which may have necessitated the granting of more responsibilities/powers to certain trusted provincial officials.

Wekhhotep I (tomb B2) was married to D $h$ wtj-htp 'Djehutihotep' ${ }^{44}$ who was described as hmt.f mrt.f $n$ st-jb.f nbt pr 'his wife, his beloved, his favourite, the lady of the house'. In no other Middle Kingdom tomb is the tomb owner's wife so prominently depicted.

${ }^{33}$ It is likely that Khnumhotep II married Tjat after the decoration of his tomb was completed. See: Ward 1984: 51-59.

${ }^{34}$ Kanawati, Evans 2014a: 17.

35 Newberry 1893: P1. 46; Kanawati, Evans 2014a: 25.

36 Although the name of Nehri's mother, $K m j$ (Ranke 1935: 345:1) is preserved in his tomb, the name of his wife has not survived (Griffith, Newberry 1893: 29, P1. 11).

37 The suggestion that the companion depicted behind Senbi in the desert hunting scene was perhaps his son is unlikely (Blackman 1914: 31).

38 Ward 1982: 124 [1058]; Favry 2005: 78.

39 See: Favry 2005: 78, 306-308.

40 Blackman 1953a: Pls 26-27; Kanawati, Evans 2014b: Pls 87-88.

${ }^{41}$ A man named Khewi wrote his name inside a cartouche and followed it with the wish 'may he be given life'. He also built a huge mud brick mastaba or pyramid at Dara in nome 13 (Kamal 1912: 128ff.).

42 Favry 2005: 307.

43 These problems have been studied by Posener 1969: especially $61 \mathrm{ff}$.

44 Ranke 1935: 408:18. 
Apart from one instance where a woman, perhaps a second wife or less likely a daughter ${ }^{45}$ with no identifying inscriptions, is shown on the north wall of the chapel in a small size clutching to Wekhhotep I's leg, ${ }^{46}$ Djehutihotep regularly appears with him in equal size ${ }^{47}$ and sits next to him, also in equal size, at the offering table. ${ }^{48}$ If the woman shown of small size was still Djehutihotep, which seems unlikely, her small size may have been aimed at focusing the scene on Wekhhotep I's role in supervising activities in the marshlands. On the other hand, in a depiction of the couple on the same north wall while watching wrestling and receiving offerings, the wife (the name again is not preserved) is not only of equal size to her husband but, contrary to traditions, is shown in front of him and holds a papyri-form staff. ${ }^{49}$ This type of staff which is often held by goddesses is probably not held by women of non-royal background..$^{50}$ It is also attested with queens such as Iput ${ }^{51}$ and Wedjebten ${ }^{52}$ wives of Pepy II. The rarity and importance of this type of staff may be demonstrated by the fact that it is attested in the well documented Old Kingdom provincial tombs only once, for the wife of Djau of Deir el-Gebrawi. Since Djau was nomarch of both Deir el-Gebrawi and Abydos, the name of his wife, Pepyankhnes, ${ }^{53}$ may well suggest a relationship with the royal in-laws at Abydos.

The possibility of the large figure of the unnamed woman in Wekhhotep I's tomb being his mother has also been considered, since mothers were rarely represented in front of their sons; yet this was usually either because of the special importance of the mother as in the Fourth Dynasty case of prince Khafkhufu and his mother at Giza, ${ }^{54}$ or that the monument belonged to the mother herself as in the stele of Henut of the Sixth Dynasty and her son Hengi of Akhmim. ${ }^{55}$ On the other hand, mothers, whether of princes or ordinary officials, were shown behind their sons. Thus prince Merib's mother was standing behind him, ${ }^{56}$ and the official Weser's mother sits behind him on the same chair. ${ }^{57}$ As Wekhhotep I's likely mother, Meres, was not prominently represented in the tomb of her own husband Senbi $I^{58}$ there is no reason to believe that she would be depicted in such a prominent position in her son's tomb. The woman depicted in front of Wekhhotep I was probably

45 It is curious that no children appear to have been depicted in tomb B1, B2 and B3.

46 Blackman 1915a: P1. 3. The possibility that this woman was the tomb owner's mother, although remote, should not be completely excluded. See, for instance, the mother of the vizier Merefnebef who is twice depicted in a similar position (Myśliwiec et al. 2004: Pls 20-21).

47 Blackman 1915a: Pls 5-6, 11, 13-14.

48 Blackman 1915a: Pl. 15.

49 Blackman 1915a: Pl. 2.

${ }^{50}$ Seven cases from the Old Kingdom have been collected by Harpur 1987: 332 (6.12). It is difficult to examine the background of some of the listed women.

51 Jéquier 1933: Fig. 22.

52 Jéquier 1928: Fig. 3.

53 Davies 1902: Pl. 6.

54 Simpson 1978: 11, Fig. 26.

55 Kanawati 1986: Fig. 30a.

56 LD II, 20-21.

57 Junker 1943: Fig. 69.

58 Blackman 1914: Pls 2, 9. 
his main wife, Djehutihotep, ${ }^{59}$ and her prominence suggests her importance, perhaps even some royal background, while the one clutching his legs is presumably a second wife. The name, Djehutihotep, may suggest a relationship to the nomarchic family at the neighbouring $15^{\text {th }}$ Upper Egyptian province of el-Bersha, where at approximately that time the nomarch Djehutihotep, dated to the reigns of Amenemhat II to Senwosret II-III, prepared one of the richest and finest Middle Kingdom tombs and represented the dragging of his colossal statue, visibly claiming royal prerogatives. ${ }^{60}$ Djehutihotep, wife of Wekhhotep I, may be the daughter or the sister of the similarly named noble of el-Bersha. If this interpretation was correct it would represent a possible case of intermarriage between members of the noble families of the neighbouring $14^{\text {th }}$ and $15^{\text {th }}$ provinces, which presumably had its effects on the status of the nobles of el-Qusiya.

The decoration of Wekhhotep I's tomb was left in various stages of completion, with some scenes partly drawn and partly sculptured, others sculptured but not coloured, while large sections retain the square gridlines characteristic of the period.$^{61}$ Like his father before him the tomb owner did not represent any of his children in his chapel, ${ }^{62}$ although he almost certainly had at least one son and one daughter by his wife Djehutihotep as we learn from the adjacent tomb B3, where the tomb owner is named Senbi (II) son of Wekhhotep (I) son of Senbi (I), and born to Djehutihotep. ${ }^{63}$ Sharing tomb (B3) with Senbi II is a woman

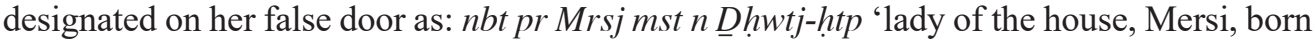
to Djehutihotep', and s3t h3itj- 'Snbj s3 Wh-htp s3 Mrsj 'daughter of the count, Wekhhotep I, son of Senbi I and son of Mersi'. It is therefore clear that Mersi was the daughter of Wekhhotep I and Djehutihotep as was the tomb owner Senbi II and accordingly they were certainly full brother and sister. The reason for not representing the sons and daughters in the chapels of Senbi I and Wekhhotep I is not entirely clear. That the children were born after the decoration was begun/completed is highly unlikely, since Wekhhotep I died well before completing the decoration of his chapel and yet his son, Senbi II, was of an age that allowed him to succeed to his father's position. Perhaps the two noblemen, Senbi I and Wekhhotep I, had a number of wives, concubines, and presumably many children as may be gathered from the description of Senbi I's wife as jm3hwwt pr hmwt 'the honoured one of the house of women' and also as evident in the large number of wives of the later noble, Wekhhotep III (tomb C1). ${ }^{64}$

A. Blackman has already identified Senbi II and Mersi of tomb B3 as brother and sister, ${ }^{65}$ but that does not explain the reason for their burial in the same tomb. The tomb has three shafts, two cut into the floor of the chapel (shafts 2 and 3) while the third (shaft 1) is

59 This is in agreement with Blackman 1915a: 12.

${ }_{60}$ Newberry 1892: especially P1. 12.

${ }^{61}$ See: Robins 1994: 70ff.

${ }_{62}$ The suggestion that the men depicted behind Senbi I (B 1) and Wekhhotep I (B 2) in the desert hunt scenes are their sons seems unlikely (Blackman 1914: 11, 19; 1915a: 6).

${ }^{63}$ Blackman 1915b: P1. 8.

${ }^{64}$ Blackman 1953b. Since the owner of tomb A3 did not reach the top position at el-Qusiya, the owner of tomb $\mathrm{C} 1$ is named Wekhhotep III and not Wekhhotep IV as occasionally referred to.

${ }^{65}$ Blackman 1953b: 6. 
accessible from the outside and descending behind the statue shrine in room B. ${ }^{66}$ Shaft 3 is $7 \mathrm{~m}$ deep, ending in a burial chamber found sealed and containing a coffin belonging to a woman named Nbt-hwt $t^{67}$ 'Nephthys' described as $s 3 t h 3 t j-$ e 'daughter of a count'. The inscriptions on her coffin, frequently with male gender, clearly indicate that it was originally made for a man and was hastily altered for the use of the noblewoman. ${ }^{68}$ The relationship of this woman to Senbi is not indicated, but the assumption that she was the 'nomarch's daughter', ${ }^{69}$ is uncertain and she may well have been his wife. Another coffin belonging to a man named Senbi was found in shaft 1 . The fact that the owner of the coffin bears only the modest title jmj-r pr 'overseer of the house' throws doubt on whether the coffin belong to the tomb owner or to a relative. ${ }^{70}$

Two false doors are placed side by side in the south wall of room A in tomb B3, one for Mersi and the second for Senbi II. It is curious that Senbi II's false door is smaller than that of his sister and inscribed only in its upper section with the most basic information. However, the re-excavation of shaft 2 produced a large number of fragments of a magnificent false door/palace façade inscribed for Senbi which was presumably destined to be fitted in one of the recesses cut in the opposite wall above the shafts, or in a similar recess to be cut elsewhere in the chapel. Senbi II probably died prematurely and his false door in the south wall of room A was perhaps hastily prepared for him before the burial as a temporary measure before the already commissioned stone false door was completed. It is doubtful if the latter has ever been fitted in its place in the chapel as there is no trace of old plaster in the recesses above the shafts or on any fragment belonging to the sides of the stone false door. All fragments of the false door were apparently dumped in shaft 2 when it was first cleared. This shaft, which presumably belonged to Mersi, is $19 \mathrm{~m}$ deep but does not lead to a burial chamber and it seems likely that it was abandoned with the possible early death of Senbi II.

Tomb B3 is the most unfinished among those belonging to the Middle Kingdom governors of el-Qusiya. Its floor is roughly cut and the south-west section in room A is much higher than the rest of the chapel. With the exception of the frame around the entrance to room B and the two small false doors, the walls of both rooms A and B are neither smoothed nor decorated. The emphasis both Senbi II and his sister Mersi placed on naming their mother Djehutihotep may well indicate her importance, and as already mentioned her representations in front of her husband Wekhhotep I in his own tomb (B2) clearly demonstrates her distinction. Although the scenes and inscriptions in tomb B3, where Djehutihotep's son and daughter, Senbi II and Mersi, are buried are very limited, enough

${ }^{66}$ Kamal 1911: 10-15; Blackman 1914: 16; 1953a: 5, P1. 3.

${ }^{67}$ Ranke 1935: 189:1.

${ }^{68}$ Kamal 1911: 11-15. According to Kamal's copy, the inscriptions on the coffin show a number of errors in gender. Thus the owner is sometimes described as $m 3^{\complement} \mathrm{C} h r w$ and others as $m 3^{\complement} t-h r w$. In the $h t p$-dj-nswt formu-

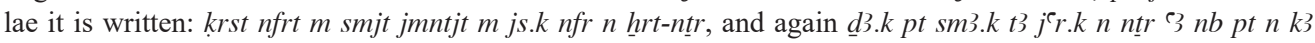

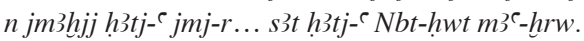

69 Blackman 1914: 16.

${ }^{70}$ Kamal 1911: 28-32. 


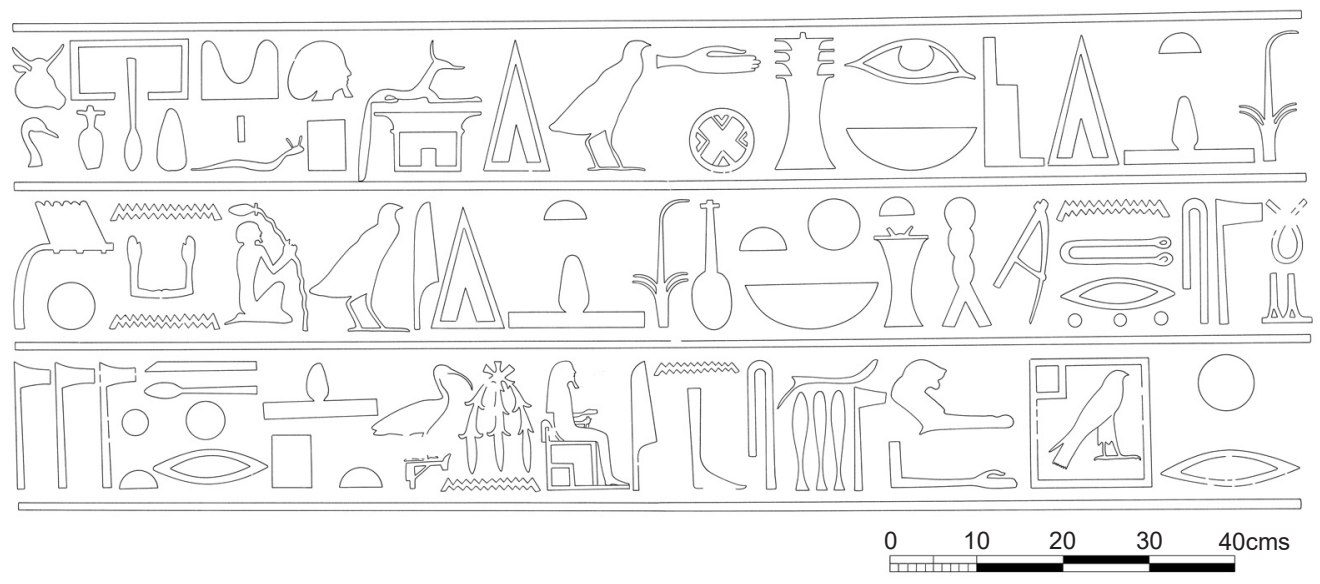

1. Tomb B3 at Meir, the lintel above the entrance to room 2 (C) Australian expedition at Meir).

was recorded to indicate their special status. Senbi II was described as $s\ulcorner\underline{s}$ sps $m r j j$ rmt 'a noble dignitary, beloved of the people' ${ }^{\prime 11}$ and the determinative after his name depicts him seated on a block chair with the $h w t$-sign at the side, ${ }^{72}$ probably declaring his royal descent (Fig. 1). This type of chair appears to be used only by gods, kings and members of the royal family. ${ }^{73}$

The only other person at el-Qusiya depicted on such a chair is the Sixth Dynasty noble Pepyankh the Middle, owner of tomb D2 at Meir. ${ }^{74}$ He was the grandson of Pepyankh the Elder and Seshseshet, the latter being probably a daughter of king Teti, and if so Pepyankh the Middle would be the great grandson of the king. ${ }^{75}$ The chair on which Mersi sits is also noteworthy. It is a block chair but with no $h w t$-sign at the side. ${ }^{76}$ Similar chairs were used in the Old Kingdom, for instance by Iufi of el-Hammamiya, who was described as 'king's daughter of his body', ${ }^{77}$ as well as by Meresankh III of Giza ${ }^{78}$ and Seshseshet wife of Remni of Saqqara. ${ }^{79}$ If Senbi II and his full sister Mersi had royal ancestry they would presumably have inherited it from their mother, Djehutihotep.

${ }^{71}$ Blackman 1953b: Pl. 8. For the rank of $s$ h , see: Moreno Garcia 1997: 38 n. 107; 99.

72 Blackman 1953b: P1. 8.

73 See, for example: Jéquier 1940: Fig. 32; Borchardt 1913: Pls 1, 42-45; Borchardt 1907: Pl. 16; Firth, Gunn 1926: Pls 55:1, 57:7; Borchardt 1964: Pl. 98 (CG 1747); Dunham, Simpson 1974: P1. 5a, Fig. 5 top; Munro 1993: Pls 12, 16, 27; Jéquier 1928: Fig. 26; 1933: Figs 1-2, 24; 1935: Pls 18-22; Hassan 1950: Fig. 46; Kanawati 2009: Pls 28, 29a, 50.

74 Blackman 1924: Pl. 5; Kanawati 2012: Pls 4c, 75a.

75 Kanawati 2012: 24-26.

76 Blackman 1953b: P1. 6.

77 El-Khouli, Kanawati 1990: 27, Pls 40, 44, 51. It is noticed that the title 'king's son/daughter' was systematically chiselled out everywhere in the tomb and it seems that it was undesirable to record this title when the bearer is buried away from the cemetery of the king to whom he/she is related (see: Kanawati 2009: 16-17).

78 Dunham, Simpson 1974: Figs 5, 8, 11.

${ }^{79}$ Kanawati 2009: Pls 24a, 48. 
The owner of tomb B4 was named Wekhhotep (II) son of Wekhhotep and Mersi, ${ }^{80}$ and it has been suggested that he represented a new branch of this noble family being the son of Mersi (of B3) and Wekhhotep son of Iam/Ima, owner of tomb A3. ${ }^{81}$ This scenario is not impossible, but unlikely considering the small size of tomb A3, its location at a great distance from group B and very close to group A of the Sixth Dynasty and the presence of many other suitable spots for such a small tomb in the vicinity of the other tombs of this family. Furthermore, if Iam/Ima, the suggested grandfather of Wekhhotep II, was the same as the one depicted in the list of ancestors shown in Wekhhotep II's chapel, then his wife was called Seneb. ${ }^{82}$ It is therefore curious that no male relative of the owner of tomb B4 was called Iam/Ima, or a female relative was named Seneb. It seems more likely that the owner of A3 was an ancestor of Senbi I of B1 rather than the husband of Mersi and the father of Wekhhotep II of B4.

The location of Wekhhotep II's tomb certainly associates him with the main branch of the noble family, the descendants of Senbi I of tomb B1. Wekhhotep (II) had three brothers carrying the same name, Wekhhotep. It may be argued that this was the result of him being the son of Wekhhotep son of Iam/Ima, yet in this case it would be difficult to explain the fact that his eldest son and a second son were both named Senbi. It was usual among members of the noble families for sons to be named after their fathers or grandfathers and daughters after their mothers or grandmothers. Not only was the mother of Wekhhotep II called Mersi, but his sister and his daughter carried the same name. The wife of Wekhhotep II was called Djehutihotep, daughter of Wekhhotep, probably named after her mother the distinguished wife of Wekhhotep I of tomb B2. The idea that Wekhhotep II belonged to a new branch of the noble family is unlikely and both he and his wife were probably descendants of Senbi I.

It is uncertain whether Wekhhotep II of B4 was depicted, like Senbi of B3, seated on a block chair with the $h w t$-sign at the side. ${ }^{83}$ However, he is the only one at el-Qusiya to hold the rare title $j t$ t $t r$ mrj $n t r$ ' father of the god, beloved of the god' ${ }^{84}$ This title is attested from the late Old Kingdom onwards but only with individuals very close to the king and the palace, although the exact relationships are disputed. ${ }^{85} \mathrm{~A}$ few examples of the holders of this title may indicate its importance and the type of men holding it. These include for instance Pepy I's possible vizier Rewer, ${ }^{86}$ who may have been the son of Shepsipuptah the king's brother-in-law. ${ }^{87}$

${ }^{80}$ Blackman 1915b: Pls 9, 12, 19, 27.

81 Blackman 1914: 11-12; 1953b: P1. 5; Favry 2005: 79.

82 Blackman 1915b: Pl. 10.

${ }^{83}$ Due to the poor preservation of some sections of the wall decoration, the type of seats on the north wall of the chapel is uncertain (Blackman 1915b: Pl. 3).

${ }^{84}$ Blackman 1915b: Pl. 19.

${ }^{85}$ For examples, see: Jones 2000: 345 [1283], 439 [1626]; and the study of Birrell 1998. See also: Baud 1999: 148-150.

${ }^{86}$ El-Fikey 1980: Pls 9, 21. He only held the title $m r j$ tr $r$.

${ }^{87}$ A man named Rewer is depicted in the tomb of Shepsipuptah described as his eldest son. The tomb owner was married to a king's daughter of his body, named Seshseshet, who may well have been Teti's daughter. 
Pepy I's father-in-law Khewi was $j t$ t $t r$ jrj- $p^{`} t$ ' father of the god, hereditary prince', ${ }^{88}$ and his son Djau was jrj-p $p^{\top} t$ mrj $n t r$ 'hereditary prince, beloved of the god' ${ }^{89}$ The vizier Teti who was buried in the cemetery of Pepy II enjoyed the honours of being jt ntr $m r j$ $n t r$ jrj-p`t s3 nswt smsw saltj nswt 'father of the god, beloved of the god, hereditary prince, king's eldest son, foster child of the king,.$^{90}$ Although his exact kinship to the king is not known, Teti must have been very close to the king and probably a royal relative. Weser of Khosam whom H.G. Fischer believes was the eldest son of at least a lesser queen held the titles of 'father of the god, beloved of the god, hereditary prince, king's eldest son'. ${ }^{91}$

Both Shemai and his son Idi of Coptos also enjoyed the distinction of being father of the god, beloved of the god, hereditary prince, foster child of the king, ${ }^{92}$ and we know that Shemai's wife held the title 'king's eldest daughter'. Whether this title should be taken literally or not, it seems likely that she was related to the king.

Bawi of Akhmim was a vizier and overseer of the army and claimed the honours of being father of the god, beloved of the god, hereditary prince, foster child of the king. He probably belongs to the Heracleopolitan period. ${ }^{93}$

Facing king Montuhotep II on a relief from Shatt el-Rigal is a man named Intef who is described as jt ntr mrj ntr s $3-R^{\complement} J n-j t . f^{\top} n h(. w) \underline{d} t^{\prime}$ 'father of the god, beloved of the god, Son of Re, Intef, may he live forever' ${ }^{94}$ The exact status of this man is disputed, but he certainly claims royal attributes.

A Twelfth Dynasty vizier named Montuhotep held the titles of hereditary prince, father of the god, beloved of the god, ${ }^{95}$ but his background is not entirely clear. The above examples show that the title father of the god, beloved of the god probably indicated royal kinship, even if a distant one. ${ }^{96}$

Offering table scenes are depicted on both sides of the false door on the west wall of the offering room in Wekhhotep II's chapel (B4).${ }^{97}$ While the upper part of the wall on either side of the false door was reserved for the tomb owner's offering table scenes, the lower part of the wall depicted similar scenes pertaining to members of his family; thus his parents share a table on the right side and his wife has a separate table on the left, their figures being approximately $2 / 3$ of those of Wekhhotep II in size. While the representation

\footnotetext{
However, as she is represented with the pigtail of youth, Rewer may have been the tomb owner's son by a previous marriage (Kanawati, Abder-Raziq 2001: 13, Pls 1a, 37).

88 Fischer 2000: Fig. 27.

89 Borchardt 1937: 111, CG 1431.

90 Jéquier 1940: 67-74. For the reading of the titles, see: Jones 2000: 345 [1283], 439 [1626], 315 [1157], 799 [2913], 986 [3645], respectively; Ward 1982: 69 [570h], 102 [850], 145 [1245], 174 [1506], respectively.

91 Fischer 1964: 41, P1. 13.

92 Fischer 1964: 37; Goedicke 1967: Figs 17, 20-21. See now: Mostafa 2014.

93 Kanawati 1989: 33-34, Fig. 17.

94 Habachi 1958: 189.

${ }_{95}$ Lange, Schäfer 1925: 153ff.

96 See also: Helck 1954: 94-95.

97 Blackman 1915b: Pl. 27.
} 
of the wife in one's tomb was very common, the depiction of parents is exceedingly rare. ${ }^{98}$ No such representations are found for instance in the other well preserved tombs of the Middle Kingdom at Meir or Beni Hassan, although parents are mentioned in a number of inscriptions in these tombs.

The only other depiction of parents at Meir is in the Sixth Dynasty tomb of Pepyankh the Middle, tomb D2. There, the tomb owner equally shows his parents at offering tables, although in this case each sits at a separate table. The size of the parents is also considerably smaller than that of their son, thus the father's figure is approximately $61 \%$ of that of his son while the mother's figure is approximately $74 \%$ of that of her son. ${ }^{99}$ It is interesting that Pepyankh the Middle combined in his wall scenes the two unusual feature depicted in tombs B3 and B4, thus like Senbi II of tomb B3 he is sitting on a block chair with the $h w t$-sign at the side and like Wekhhotep II of tomb B4 he represented in his chapel both his parents at the offering table. ${ }^{100}$ The depiction of parents in an official's tomb was presumably not only to allow them to partake in offerings presented to him and therefore fulfilling his filial duties, but probably also to emphasise his noble lineage. In addition to the two above-mentioned examples at Meir, one can cite the Old Kingdom example of Djau of Deir el-Gebrawi, ${ }^{101}$ and the Middle Kingdom example of Djehutihotep of el-Bersha. ${ }^{102}$

One of the most remarkable representations in Wekhhotep II's chapel (B4) is the depiction of his ancestors on the west wall, south of the statue recess and facing the visitor to the chapel. ${ }^{103}$ These are portrayed in six registers, each divided into two sub-registers, the upper one containing the figures of the men sitting on ebony chairs with lions' legs and holding staffs, while the lower sub-register contains figures of the wives squatting and holding alternatively a lotus flower or a folded cloth (Fig. 2). Each register commemorates ten men, each with his wife, or at least the main wife. The bottom register contains only nine couples, thus the total men and women commemorated are fifty-nine couples. All the men are designated as $h 3 t j-{ }^{-}$'count', and all women are described as $h m t . f$ 'his wife'. The height of the sub-register for women is approximately 3/4 of that for men. Next to the figures the tomb owner wrote: I did this in order that their names would remain established for ever, in order that invocation offerings may come forth for them with the daily requirements every day ${ }^{104}$ by the lector priests and the wab-priests of the tomb, they existing eternally.

Wekhhotep II's commemoration of his ancestors is a virtue claimed by other Egyptians, but is particularly evident in the inscriptions of the nobles of the neighbouring Hare

98 For a possible reason of this phenomenon, see: Kanawati 1981: 213ff.

99 Blackman 1924: P1. 15; Kanawati 2012: 47, P1. 83.

100 Blackman 1924: Pls 5, 15; Kanawati 2012: Pls 75a, 83.

101 Davies 1902: Pl. 10. The father was the son of Ibi, probably a descendant of the royal in-laws at Abydos.

102 Newberry 1892: P1. 33. Djehutihotep here emphasised that he was the son of Kay, who was the son of the important Nehri. The similarities between the representations in the tombs of Djau and Djehutihotep are evident.

103 Blackman 1915b: Pls 10-11.

104 For $m$ hrt-hrw nt $r^{c}-n b$, see: Hannig 2003: 1019. 

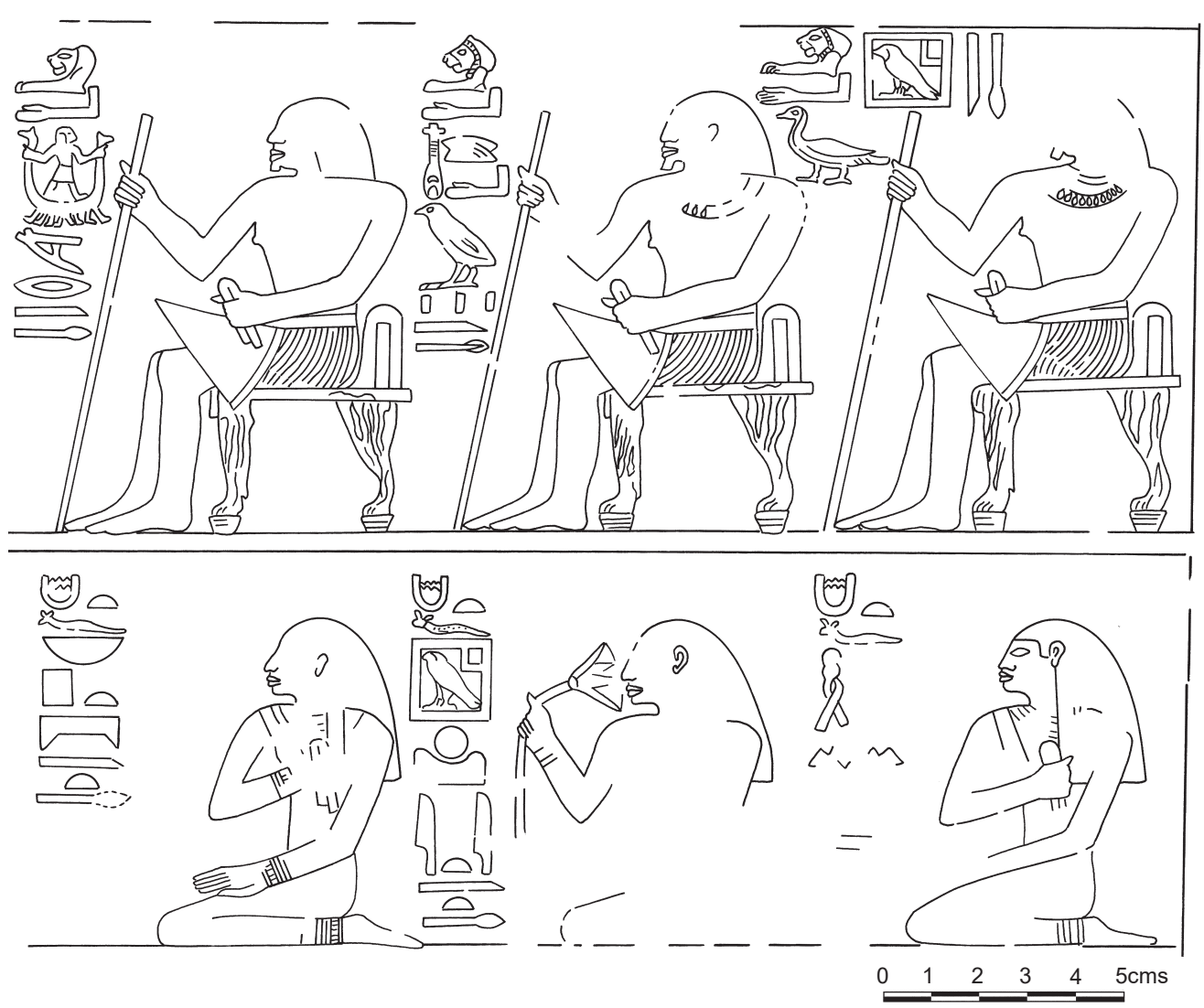

2. Tomb B4 at Meir, part of the representation of the ancestors (@ Australian expedition at Meir).

nome. Commemorative inscriptions are recorded in a number of tombs at Sheikh Said and el-Bersha, occasionally with claims of restoration work undertaken to the ancestors' tombs. ${ }^{105}$ The similarity in the action of the nobles of the $14^{\text {th }}$ and $15^{\text {th }}$ Upper Egyptian provinces suggests once more the close ties between the two families and perhaps the intermarriages between their members. It is also interesting that commenting on the decoration of tomb B4, Blackman has noticed that in marked contrast with the naturalistic sculpture in B, Nos. 1 and 2, they resemble in style, except for a much mutilated fishing and fowling scene, the fine but conventional reliefs in the XIIth Dynasty tomb-chapels at el-Bersheh. ${ }^{106}$ However, while commemorative inscriptions were recorded in individual tombs in nome 15, Wekhhotep II's depiction of fifty-nine couples of his ancestors is unique.

105 Davies 1901: 38-39, Pls 29e, 30; Griffith, Newberry 1893: 10-11.

106 Blackman 1914: 9. Close similarities also exist between the themes depicted in wall scenes in the tombs of el-Bersha and Beni Hassan, for example the representation of the guards accompanying Djehutihotep of el-Bersha and Khnumhotep II of Beni Hassan (Newberry 1892: Pls 13, 29; Kanawati, Evans 2014a: Pls 120, 123 ) and the tomb owner in a fowling scene personally pulling the rope to close the clap net while seated on a chair (Newberry 1892: P1. 17; Kanawati, Evans 2014a: Pls 67, 137). 
Blackman's description of the commemorated couples as representing a 'list of Ukh-hotp's predecessors in the nomarchy and their wives' ${ }^{107}$ is doubtful, for the number appears to be too high for governors from the Sixth to the Twelfth Dynasties, even if they continued to rule the province during the First Intermediate period. We have no reason to believe that all the men were governors, although they all enjoyed the rank of $h 3 t j-c$ 'counts' which suggests that they held high administrative responsibilities. El-Qusiya was certainly an important administrative centre, yet we are not told that they all belonged to el-Qusiya and some may have been in-laws from other provinces. However, the presence of certain individuals known to us in the list suggests that the compiler had some reliable sources, including probably the earlier but still accessible tombs. ${ }^{108}$

Two of these individuals are $\mathrm{Hpj}_{-} \mathrm{C}_{3}$ 'Hepi the great' and his wife Phrt 'Pekhert'. The former may well be the Sixth Dynasty Hepi/Sobekhotep/Niankhpepy, the son of Pepyankh the Elder and Seshseshet, and the father of Pepyankh the Middle, while the latter would be an abbreviated form of his wife's name, Phr-nfrt 'Pekhernefert'. ${ }^{109}$ This man died in the capital and was buried at Saqqara, thus never succeeded to the governorship of el-Qusiya, ${ }^{110}$ yet he is represented in the chapel of his son Pepyankh the Middle at Meir ${ }^{111}$ and is included in the list of ancestors. The name of the man immediately in front of him in the list is lost, but his wife is named Hwt-j ${ }^{\top} h$ 'Hewetiaah', a name not attested except for the wife of Pepyankh the Middle (Fig. 3). ${ }^{112}$

Another noble who may be identified in the list is Iam/Ima and his wife Snb 'Seneb'. ${ }^{113}$ This man may be the father of the owner of tomb A3 who was described in his tomb as well as in the list as 'count', but who has no other titles to suggest that he governed the province. The earlier rejection of his identification with the grandfather of Wekhhotep II (B4) may be further supported by the evidence from the list of ancestors, for the man who immediately precedes him is named Rnsj 'Rensi' and the one who succeeds him is Jpj 'Ipi' and not Wekhhotep. It is also curious that for a man with such unparalleled interest in his ancestors as was Wekhhotep II, neither the name of Iam/Ima nor that of his wife Seneb is given to any of his descendants or is carried by any of his dependents. Instead the names commonly used are those of Senbi, Wekhhotep and Mersi, all names belonging to the main noble family buried in tombs B1 to B4.

The ancestors list is not fictitious, for all the men are named and it is remarkable that such a historical record existed or could be compiled, particularly considering the turbulent time which the country probably experienced during the First Intermediate Period.

107 Blackman 1915b: 16.

108 The drawing of square grids above a sculptured and painted scene in the tomb of Pepyankh the Black (A2) at Meir was presumably done by Middle Kingdom artists with the purpose of copying details of the earlier scene, which suggests that the tomb was accessible at least until the Middle Kingdom (see: Kanawati 2011a: 494-495).

109 Blackman 1924: Pl. 15; Kanawati 2012: Pl. 83.

110 Kanawati 2004a: 49-61.

111 Blackman 1924: Pl. 15; Kanawati 2012: P1. 83.

112 Blackman 1924: Pl. 15; Kanawati 2012: Pl. 83; Ranke 1935: 234:28.

113 Blackman 1953b: Pl. 5. 
3. Tomb B4 at Meir, the representation of Hewetiaah, wife of Pepyankh the Middle (C) Australian expedition at Meir).

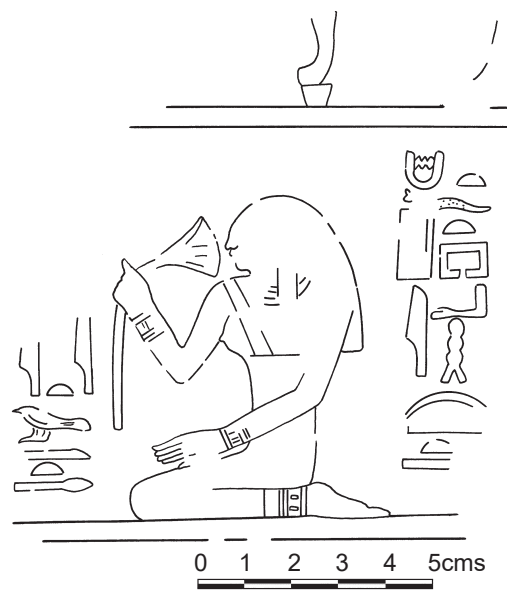

On the other hand the total accuracy of the list could certainly not be verified, although the compiler is probably to be commended for not including doubtful information, which may be gathered from the study of the surviving names of the nobles' wives. Out of thirty-eight fully or partly preserved names, Blackman reads four (or possibly five) as Meritef. ${ }^{114}$ This is the only occurrence of the name in H. Ranke's work, listed with a question mark, ${ }^{115}$ and if read as Mrjj-jt.f it should indicate a masculine name. In addition, four or five instances of the same name are the largest number of any name in the list. It appears that this is not a name but the usual epithet describing wives, hmt.f mrjjt.f 'his wife, his beloved', and the writing of mrjjt.f is typical in the Middle Kingdom, rather than mrt.f which was common in the Old Kingdom. It is true that none of the named wives in the list is so described, but it seems that with the limited space available for labelling each wife, it was impossible to include both the name and the designation 'his beloved'. If so, it would demonstrate the compiler's acknowledgement of his inability to find out the names of the wives of these important men, which would suggest his reliability. Wekhhotep II's commemorative list of his ancestors is unique in private inscriptions, but can only be compared in its concept to royal king lists.

The last decorated tomb belonging to a member of the noble family at Meir is $\mathrm{C} 1$ of Wekhhotep III. His tomb is the highest on the cliff, beautifully designed and elaborately

\footnotetext{
114 Blackman 1915b: 16-19. Only 31 or 32 are seen in the plates (Blackman 1915b: Pls 10-11).

115 Ranke 1935: 162:2.
} 
decorated. Wekhhotep III represented himself in such forms and used formulae that are strictly royal. He appears holding the ' $n h$-sign, ${ }^{116}$ with the text $s 3{ }^{C} n h \underline{d} d \mathbf{d}$ ws $n b$ snb $n b$ $3 w t-j b n b$ 'all protection, life, stability and dominion, all health, all joy' written behind him, ${ }^{117}$ and wears a kilt decorated with multiple signs of $s 3$ ' $n h \underline{d} \underline{d} d w 3 s$. Royal attributes are particularly emphasised in the area of the statue-recess, where he is presented with ' $n h$-signs and $d d$-emblem by figures squatting on a stand supported by the sign for $s m 3$ 'unite', with a bunch of lilies to the left (south), and a bunch of papyrus to the right (north), probably representing Upper and Lower Egypt. In addition, the signs for $d d w 3 s{ }^{\top} n h n b$ are painted in the vicinity. In the lower register the tomb owner is depicted seated at either end of the scene, with the two figures facing each other, identified by the title 'overseer of priests' and name and wearing what appears to be a bull's tail. Between his figures is the sign for $s m 3$ ' unite'. On the north wall of the recess a sm-priest is standing in the top register and pronouncing the following curious recitation: htp dj $n s w t R^{e}\left(\right.$ ?) $n$ h3tj- ${ }^{\mathrm{C}} \mathrm{jmj}-\mathrm{r}$ $h m w$-ntr Wh-htp $h^{\top}(. w) m n s w t h^{\top}(. w) m$ bjtj $n \underline{d} t \underline{d} t$ ' an offering which the king gives and Re to the count, the overseer of priests, Wekhhotep, that he may appear in glory as/like the king of Upper Egypt and may appear in glory as/like the king of Lower Egypt, for ever and ever'. Beneath the seated figure of the tomb owner, deities present him with trays of offerings as well as the signs of ' $n h$ and $w 3 s$ 'life and dominion'.

W. Grajetzki is certainly correct in suggesting that the unusually large number of women represented around Wekhhotep is found elsewhere only in funerary monuments of kings. Thus Mentuhotep II, Senwosret I and Senwosret III, for example, were buried surrounded by their wives and daughters. ${ }^{118}$ However, Wekhhotep III was not merely surrounded by his wives, daughters and perhaps concubines, but curiously all the working classes were also of women; not only musicians, dancers and entertainers, but also those employed in carrying the offerings, as well as in fishing, fowling, working in the marshes and herding both domestic and desert animals were all females. Only in the statue recess are some figures of male priests and these are performing rituals only men could celebrate. Wekhhotep III presents us with a unique case of a man who surrounded himself with women and as this was totally contrary to the norm in tomb wall scenes we should probably take it as a reflection of reality, whatever the reasons for it might have been.

A study of the cemetery of Meir, both from the published data as well as from personal investigation, leaves little doubt that Wekhhotep III was the last to decorate a tomb $(\mathrm{C} 1)$ on the mountain. Another count and overseer of priests known from Meir is Khakheperreseneb/Iy, whose coffin and canopic chest were discovered by A. Kamal in an undecorated tomb, perhaps in section $\mathrm{C}$ of the cemetery and with a likely date shortly after that of Wekhhotep III. ${ }^{119}$ As Wekhhotep II of tomb B4 is securely dated to the reign of

\footnotetext{
116 Blackman 1953b: Pls 11, 18.

117 Blackman 1953b: Pl. 13.

118 Grajetzki 2009: 117-118.

119 Rigault 2015: 325-331.
} 
Amenemhat II, ${ }^{120}$ Wekhhotep III may well be dated to the reigns of Senwosret II and/or Senwosret III. ${ }^{121}$ The relationship of Khakheperreseneb to the Senbi-Wekhhotep family is not known, and according to the available data he is the last attested governor of the province in the Twelfth Dynasty.

The evident end or at least drastic curtailment of the power of the provincial nobility by Senwosret III has been observed in other nomes and was explained as the king's response to the increasing authority and apparently the independence of the local rulers, who had been gradually transforming themselves into local dynasties and becoming almost as powerful as the king himself. ${ }^{122}$ An examination of the evidence from the neighbouring provinces, with which el-Qusiya no doubt had strong ties, shows a similar trend.

Thus at el-Bersha (nome 15) Djehutihotep (tomb no. 2), who served under Senwosret II and Senwosret III, ${ }^{123}$ prepared one of the richest private tombs of the Middle Kingdom and depicted in it the transportation of his huge colossus, like that of a king. ${ }^{124}$ On the other hand, his epithets, including those of jmj-jb $\mathrm{Hr} n b^{\text {' }} \mathrm{h}$ 'confidant of Horus, lord of the palace' and smr w'tj nj mrwt 'sole companion, possessor of love', showed his closeness to the king. ${ }^{125}$ The latter title is, according to M. Baud, a way of indicating the proximity and the attachment to the king, similar to that of a father and son. ${ }^{126}$

Khnumhotep II (tomb no. 3) of Beni Hassan (nome 16) was appointed as overseer of the eastern desert by Amenemhat II, but the decoration of his magnificent tomb must have been completed during the reign of Senwosret II who is mentioned in the tomb owner's biographical inscriptions, ${ }^{127}$ and we do not know if he survived into the reign of Senwosret III. On the north wall of his chapel Khnumhotep II represents his reception of a group of Asiatic, men, women and children, headed by the 'ruler of the foreign land, Ibsha'. ${ }^{128}$ No contemporary similar depictions are found anywhere in the country and one wonders if by such an action Khnumhotep II had exceeded his authorities and antagonised the king. No later major tombs are found at Beni Hassan and Khnumhotep II's likely son, Khnumhotep III spent a part of his career in the capital and was finally made vizier. ${ }^{129}$ Another son, Khnumhotep IV, acquired the ranks of $j r j-p^{`} t$ and $h 3 t j-{ }^{-}$'hereditary prince

${ }^{120}$ Blackman 1915b: P1. 19. This is the only attested record of a Middle Kingdom cartouche of a monarch at Meir.

121 See also Blackman 1914: 13. N. Favry (2005: 54-55) suggests the reign of Senwosret III, but admits that this is with little certitude.

122 See, for example: Grimal 1992: 167-168.

123 Newberry 1892: P1. 5; Favry 2005: 56.

124 Newberry 1892.

125 Newberry 1892: Pl. 16. For the reading of the latter title, see: Jones 2000: 894 [3277].

126 Baud 1999: 265.

127 Newberry 1893: Pls 25-26; Kanawati, Evans 2014a: 25, 48.

128 Newberry 1893: Pl. 30; Kanawati, Evans 2014a: P1. 124.

129 Nelson-Hurst 2015: 257-272, particularly 266. 
and count' and started the cutting of a rather modest tomb adjacent to that of his father (tomb no. 4), yet this was abandoned at a very early stage. ${ }^{130}$

Grajetzki writes that some local governors dated events according to their years of rule and used royal symbols about the same time, but not to the same extent as in the case of Wekhhotep III. However he draws the attention to the fact that these governors often referred to the king in their tombs and concluded that he does not believe that anyone challenged the power of the king, but admits that large provincial tombs disappeared under Senwosret III. ${ }^{131}$ It is true that we have no evidence that any of the governors actually challenged the authority of the king, yet it seems doubtful if the latter would have been pleased with the grand claims made by some of his top administrators and the royal prerogatives they attributed to themselves.

The almost simultaneous end of Middle Kingdom nobility in different provinces, even though presumably not everywhere at exactly the same time, appears to have been the result of a planned central policy, although each province was dealt with differently and as the opportunity presented itself. Thus despite Wekhhotep III's unusually large number of wives, perhaps as many as ten or more, the only offspring recorded in the scenes of his tomb ${ }^{132}$ and in two group statues ${ }^{133}$ is one daughter: s3t.f mrjjt.f Nbt-hwt-hnwt.sn $n^{134}$ 'his daughter, his beloved, Nephthys-henutsen'. Wekhhotep III was almost certainly a polygamist, ${ }^{135}$ and such a large number of wives presumably aimed at producing more offspring and a male offspring in particular, but it appears that this did not eventuate. While there is no evidence of aggressive royal intervention to bring the power of the ruling family of el-Qusiya to an end, the lack of a male successor to Wekhhotep III presented the opportunity for the king to appoint Khakheperreseneb and apparently no successor.

The education and employment of Khnumhotep III of Beni Hassan in the capital, and even his promotion to the vizierate, may appear, on the surface, as royal favours, yet perhaps in reality they could have been a tactful way to put an end to the growing power of this strong family at Beni Hassan at a distance from the capital. It is also possible that the same policy applied to the sons of nomarchs of other provinces, although the evidence for this needs much further investigation. Senwosret III, or his successor, was not the first to adopt this plan of action, and it seems that the Middle Kingdom king was emulating the policy of an Old Kingdom predecessor. Following the creation of the title hrj-tp 3 'great overlord' of the province and the appointment of residing governors by Teti of the Sixth Dynasty, his son Pepy I brought the sons of the nomarchs to be $k m 3 t$ 'formed' in

130 Newberry 1893: 7, Pls 39-40, and personal examination.

131 Grajetzki 2009: 113-114, 117.

132 Blackman 1953b: Pl. 13. Apparently the same daughter appears in other scenes, although the name is not preserved (Blackman 1953b: Pls 13, 15, 17-18).

${ }^{133}$ One of the statues is now in the Egyptian Museum, Cairo (Egyptian Museum), and the other in the Museum of Fine Arts, Boston (Museum of Fine Arts: acc. no. 1973.87).

134 Ranke 1935: 189:4.

135 For the practice of polygamy in Egypt, see: Simpson 1974: 100-105; Kanawati 1976: 149-160; McCorquodale 2013: 67ff. For the opposite view, see: Ward 1984: 58 n. 5. 
the capital. ${ }^{136}$ This was not merely for their education, since they were employed by the central government in various capacities and built tombs at Saqqara, ${ }^{137}$ before Merenre reversed his father's policy by allowing them to return to their respective provinces. ${ }^{138}$ The evidence suggests that the almost simultaneous end of rich burials in the different Upper Egyptian provinces was arranged by Senwosret III, probably in reaction to many provincial nobles going too far in claiming royal prerogatives.

\section{References}

Baines, J., Málek, J. 1980: Atlas of Ancient Egypt, Oxford

Baud, M. 1999: Famille royale et pouvoir sous l'Ancien Empire égyptien, BiEtud 126, Cairo Birrell, M.D. 1998: 'Father of the God Beloved of the God': The Egyptian Title it-ntr mry-ntr and the Rite of Royal Investiture, PhD thesis, Macquarie University, Sydney

Blackman, A.M. 1914: The Rock Tombs of Meir I: The tomb-chapel of Ukh-hotp's son Senbi, ASEg 22, London

Blackman, A.M. 1915a: The Rock Tombs of Meir II: The tomb-chapel of Senbi's son Ukh-hotp (B, No. 2), ASEg 23, London

Blackman, A.M. 1915b: The Rock Tombs of Meir III: The tomb-chapel of Ukh-hotp son of Ukh-hotp and Mersi (B, No. 4), ASEg 24, London

Blackman, A.M. 1924: The Rock Tombs of Meir IV: The tomb-chapel of Pepi'onkh the middle son of Sebkhotpe and Pekhernefert (D, No. 2), ASEg 25, London

Blackman, A.M. 1953a: The Rock Tombs of Meir V: The tomb-chapels A, No. 1 (that of Ni-'ankh-Pepi the Black), A No. 2 (that of Pepi'onkh with the "good name" of Heny the Black), A No. 4 (that of Hepi the Black), D No. 1 (That of Pepi), and E, Nos 1-4 (those of Meniu, Nenki, Pepi'onkh and Tjetu), ASEg 28, London

Blackman, A.M. 1953b: The Rock Tombs of Meir VI: The tomb-chapels of Ukhhotpe son of Iam (A, No. 3), Senbi son of Ukhhotpe son of Senbi (B, No. 3), and Ukhhotpe son of Ukhhotpe and Heny-hery-ib (C, No. 1), ASEg 29, London

Borchardt, L. 1907: Das Grabdenkmal des Königs Ne-user-re‘, Leipzig

Borchardt, L. 1913: Das Grabdenkmal des Königs S'azḥu-re' II: Die Wandbilder, WVDOG 26, Leipzig

Borchardt, L. 1937: Denkmäler des alten Reiches (Aussen den Statuen) 1, Catalogue général des antiquités égyptiennes du Musée du Caire N ${ }^{\text {os }}$ 1295-1541, Berlin

Borchardt, L. 1964: Denkmäler des alten Reiches (Aussen den Statuen) II, Catalogue général des antiquités égyptiennes du Musée du Caire Nos $1542-1808$, Le Caire

Davies, N. de G. 1901: The Rock Tombs of Sheikh Saïd, ASEg 10, London

Davies, N. de G. 1902: The Rock Tombs of Deir el-Gebrâwi 2: Tomb of Zau and Tombs of the Northern Group, ASEg 12, London

\footnotetext{
136 This is according to the biography of Qar of Edfu (Urk. I, 254:1).

137 See, for example: Kanawati 2004b: 51-62; Moreno Garcia 2005: 95-128; Kanawati 2011b: $217-231$. Niankhpepy of el-Qusiya was even buried at Saqqara (Kanawati 2004a: 49-61).

138 Urk. I, 254:3-4.
} 
Dunham, D., Simpson, W.K. 1974: Giza Mastabas 1: The Mastaba of Queen Mersyankh III G 7530-7540, Boston

Egyptian Museum: http://egyptopia.com/Statue+of+Ukh-hotep+and+His+Family+The+E gyptian+Museum_30_382_87_en.html (accessed November 30, 2014)

El-Fikey, S.A. 1980: The Tomb of the Vizier Rē'-wer at Saqqara, EgToday 4, Warminster El-Khouli, A., Kanawati, N. 1989: Quseir el-Amarna: The Tombs of Pepy-ankh and Khewen-wekh, The Australian Centre for Egyptology: Reports 1, Sydney

El-Khouli, A., Kanawati, N. 1990: The Old Kingdom Tombs of El-Hammamiya, The Australian Centre for Egyptology: Reports 2, Sydney

Favry, N. 2005: Le nomarque sous le règne de Sésostris I ${ }^{\mathrm{er}}$, Les institutions dans l'Égypte ancienne 1, Paris

Firth, C.M., Gunn, B. 1926: Teti Pyramid Cemeteries 2, Cairo

Fischer, H.G. 1964: Inscriptions from the Coptite Nome, Dynasties VI-XI, AnOr 40, Rome

Fischer, H.G. 2000: Egyptian Women of the Old Kingdom and of the Heracleopolitan Period, 2nd ed., New York

Fisher, W.B. 1971: The Middle East: A Physical, Social and Regional Geography, London

Goedicke, H. 1967: Königliche Dokumente aus dem Alten Reich, ÄgAbh 14, Wiesbaden

Grajetzki, W. 2009: Court Officials of the Egyptian Middle Kingdom, Bristol Classical Press Egiptology, London

Griffith, F.L., Newberry, P.E. 1893: El Bersheh II (Nine Inscribed Tombs), ASEg 4, London

Grimal, N. 1992: A History of Ancient Egypt, Oxford

Habachi, L. 1958: God's fathers and the role they played in the history of the First Intermediate Period, ASAE 55, 167-190

Hannig, R. 2003: Ägyptisches Wörterbuch 1. Altes Reich und Erste Zwischenzeit, Kulturgeschichte der antiken Welt 98, Hannig-Lexica 4, Mainz a/Rhein

Harpur, Y. 1987: Decoration in Egyptian Tombs of the Old Kingdom: Studies in orientation and scene content, London-New York

Hassan, S. 1950: The Mastabas of the Sixth Season and their Description, Excavations at Gîza 6:3, Cairo

Helck, W. 1954: Untersuchungen zur den Beamtentiteln des ägyptischen Alten Reiches, $\ddot{A g F o r s c h ~ 18, ~ G l u ̈ c k s t a d t ~}$

Helck, W. 1974: Die altägyptischen Gaue, Wiesbaden

Jéquier, G.1928: La pyramide d'Oudjebten, FouillesSaqq, Cairo

Jéquier, G. 1933: Les pyramides des reines Neit et Apouit, Cairo

Jéquier, G. 1935 : La pyramide d'Aba, Cairo

Jéquier, G. 1940: Le monument funéraire de Pepi II 3. Les approches du temple, Cairo

Jones, D. 2000: An Index of Ancient Egyptian Titles, Epithets and Phrases of the Old Kingdom, BAR-IS 866 (I), Oxford

Junker, H. 1943: Gîza 6, Wien-Leipzig

Kamal, A. 1911: Rapport sur les fouilles exécutées dans la zone comprise entre Deïrout au nord et Deîr-el-Ganadlah au sud, ASAE 11, 3-39 
Kamal, A. 1912: Fouilles à Dara et à Quçéîr el-Amarna, ASAE 12, 128-142

Kanawati, N. 1976: Polygamy in the Old Kingdom of Egypt?, SAK 4, 149-160

Kanawati, N. 1980: Governmental Reforms in Old Kingdom Egypt, Warminster

Kanawati, N. 1981: The living and the dead in Old Kingdom tomb scenes, SAK 9, 213-225

Kanawati, N. 1986: The Rock Tombs of El-Hawawish: The Cemetery of Akhmim 6, Sydney

Kanawati, N. 1989: The Rock Tombs of El-Hawawish: The Cemetery of Akhmim 9, Sydney

Kanawati, N. 2003: Conspiracies in the Egyptian Palace: Unis to Pepy I, London-New York

Kanawati, N. 2004a: Niakhpepy/ Sebekhetep/ Hepi: Unsual tomb and unusual career, GöttMisz 201, 49-61

Kanawati, N. 2004b: Interrelation of the capital and the provinces in the Sixth Dynasty, $B A C E$ 15, 51-62

Kanawati, N. 2009: The Teti Cemetery at Saqqara 9: The Tomb of Remni, The Australian Centre for Egyptology. Reports 28, Oxford

Kanawati, N. 2011a: Art and Gridlines: The copying of Old Kingdom scenes in later periods, [in:] Bárta, M., Coppens, F., Krejčí, J. (Eds), Abusir and Saqqara in the Year 2010/2, Prague, 483-496

Kanawati, N. 2011b: The Memphite Tomb of Qar of Edfu, [in:] Callender, V.G., Bareš, L., Bárta, M., Janák, J., Krejčí, J. (Eds), Times, Signs and Pyramids: Studies in Honour of Miroslav Verner on the Occasion of His Seventieth Birthday, Prague, 217-231

Kanawati, N. 2012: The Cemetery of Meir 1: The Tomb of Pepyankh the Middle, Oxford Kanawati, N., Abder-Raziq, M. 2001: The Teti Cemetery at Saqqara 7: The Tombs of Shepsipuptah, Mereri (Merinebti), Hefi and Others, The Australian Centre for Egyptology. Reports 17, Warminster

Kanawati, N., Evans, L. 2014a: Beni Hassan 1: The Tomb of Khnumhotep II, The Australian Centre for Egyptology. Reports 36, Oxford

Kanawati, N., Evans, L. 2014b: The Cemetery of Meir 2: The Tomb of Pepyankh the Black, The Australian Centre for Egyptology. Reports 34, Oxford

Lange, H.O., Schäfer, H. 1925: Grab- und Denksteine des Mittleren Reichs im Museum von Kairo II, Catalogue général des antiquités égyptiennes du Musée du Caire No. 20001-20780, Berlin

Lashien, M. 2015: The Nobles of El-Qusiya in the Sixth Dynasty: Archaeological and Historical Study, PhD thesis, Macquarie University, Sydney

McCorquodale, K. 2013: Representations of the Family in the Egyptian Old Kingdom: Women and marriage, BAR-IS 2513, Oxford

Moreno Garcia, J.-C. 1997: Études sur l'administration, le pouvoir et l'idéologie en Égypte, de l'Ancien au Moyen Empire, AegLeod 4, Liège

Moreno Garcia, J.-C. 2005: Deux familles de potentats provinciaux et les assises de leur pouvoir: Elkab et El-Hawawish sous la VI ${ }^{\mathrm{e}}$ dynastie, $R d E$ 56, 95-128

Mostafa, M.F. 2014: The Mastaba of $\breve{S} m 3 j$ at Naga Kom el-Koffar, Qift 1, Cairo

Munro, P. 1993: Der Unas-Friedhof Nord-West I: Topographisch-historische Einleitung.

Das Doppelgrab der Königinnen Nebet und Khenut, Mainz a/Rhein

Museum of Fine Arts: www.mfa.org (accessed November 30, 2014) 
Myśliwiec, K., Kuraszkiewicz, K., Czerwik, D., Godziejewski, Z., Kaczmarek, M., Kowalska, A., Radomska, M., Rzeuska, T. 2004: Saqqara I: The Tomb of Merefnebef, Varsovie

Nelson-Hurst, M.G. 2015: The (social) House of Khnumhotep, [in:] Miniaci, G., Grajetzki, W. (Eds), The World of Middle Kingdom Egypt (2000-1550 BC). Contributions on archaeology, art, religion, and written sources, Middle Kingdom Studies 1, London, 257-272

Newberry, P.E. 1892: El-Bersheh I: The Tomb of Tehuti-Hetep, ASEg 3, London

Newberry, P.E. 1893: Beni Hasan I, ASEg 1, London

Newberry, P.E. 1894: Beni Hasan II, ASEg 2, London

Posener, G. 1969: Littérature et politique dans l'Égypte de la XII ${ }^{\mathrm{e}}$ Dynastie, Bibliothèque de l'École des Hautes Études 307, Paris

Ranke, H. 1935: Die ägyptischen Personennamen I: Verzeichnis der Namen, Glückstadt

Redford, D.B. 1967: The father of Khnumhotpe II of Beni Hasan, JEA 53, 158-159

Rigault, P. 2015: The canopic chest of Khakheperreseneb/Iy - Louvre E 17108, [in:] Miniaci, G., Grajetzki, W. (Eds), The World of Middle Kingdom Egypt (2000-1550 BC), Middle Kingdom Studies 1, London, 325-331

Robins, G. 1994: Proportion and Style in Ancient Egyptian Art, London

Simpson, W.K. 1974: Polygamy in Egypt in the Middle Kingdom?, JEA 60, 100-105

Simpson, W.K. 1978: The Mastabas of Kawab, Khafkhufu I and II, Giza Mastabas 3, Boston

Ward, W.A. 1982: Index of Egyptian Administrative and Religious Titles of the Middle Kingdom, Beirut

Ward, W.A. 1984: The case of Mrs. Tchat and her sons at Beni Hasan, GöttMisz 71, 51-59 


\section{ÉTUDES et TRAVAUX XXX / 2017}

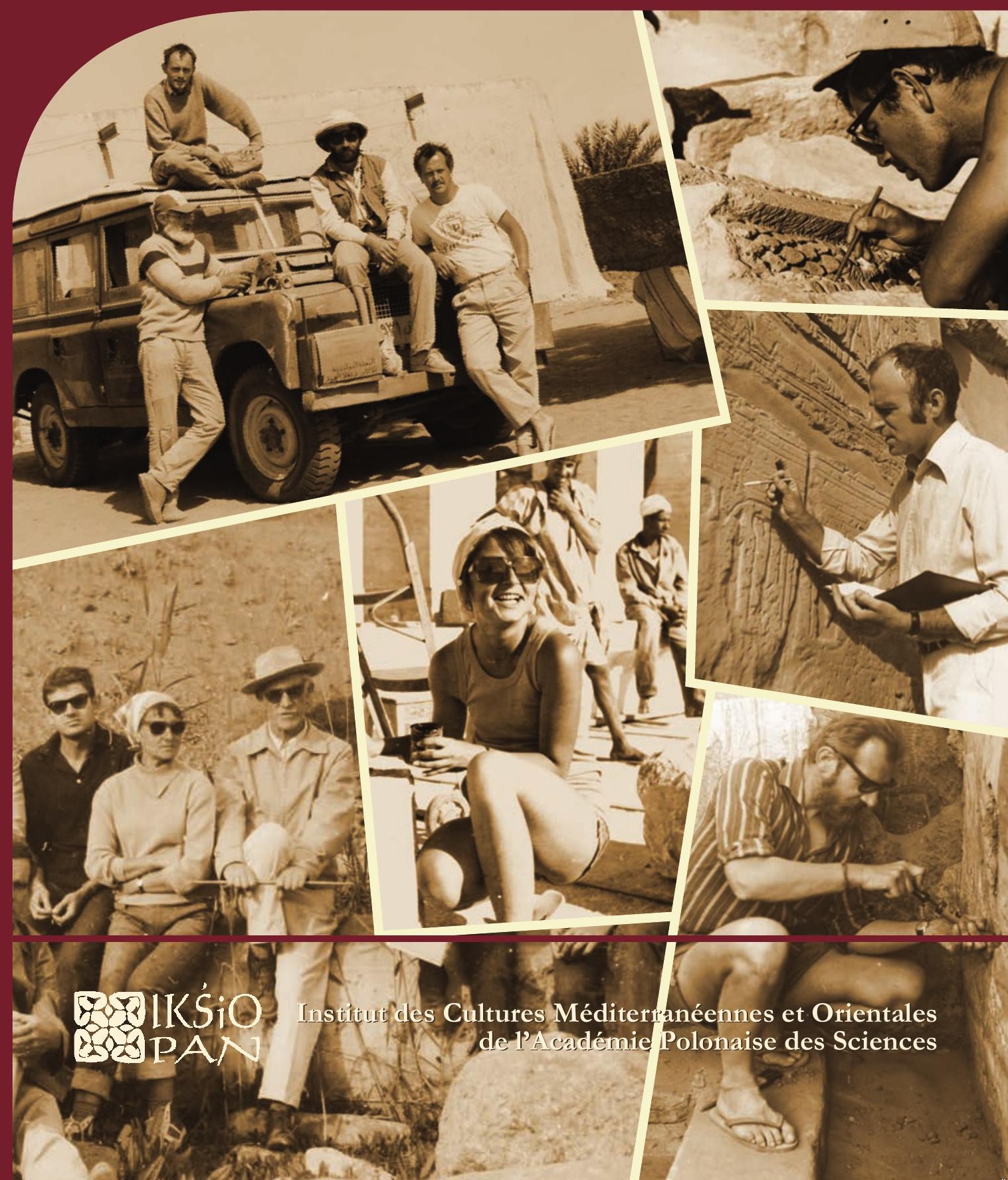




\title{
COMITÉ DE RÉDACTION SCIENTIFIQUE
}

Maciej Makowski - rédacteur en chef

Jadwiga Iwaszczuk - rédacteur et sécretaire de la rédaction

Mariusz Drzewiecki - rédacteur

Maciej G. Witkowski - rédacteur

\section{CONSEIL SCIENTIFIQUE DU JOURNAL}

M. Kobusiewicz (IAE PAS, Warszawa), E. Laskowska-Kusztal (IMOC PAS, Warszawa),

D. Michaelides (University of Cyprus, Nicosia),

J.Ch. Moretti (IRAA-MOM, Université de Lyon 2/CNRS),

D. Raue (Ägyptisches Museum der Universität Leipzig), P. Reynolds (ICREA, Barcelona),

D. Welsby (British Museum, London)

\section{COMITÉ SCIENTIFIQUE DE LECTURE}

J. Holaubek (Institut für Ägyptologie, Wien), S. Ikram (AUC, Cairo),

K. Innemée (Universiteit Leiden), J. McKenzie (Faculty of Oriental Studies, University of Oxford),

N. Strudwick (University of Cambridge), A. Loprieno-Gnirs (Universität Basel),

Ch.E. Loeben (Museen für Kulturgeschichte, Hannover), Y. Tristant (Macquarie University, Sydney),

V.W.J. van Gerven Oei (University of Aberdeen), A. Peignard-Giros (HiSoMA-MOM, Université de Lyon 2/CNRS), J.A. Ostrowski, E. Papuci-Władyka, J. Śliwa (IA JU, Kraków), R. Czerner (WUST, Wrocław), A. Ćwiek (IA AMU, Poznań), M. Wiewióra (IA NCU, Toruń), K. Domżalski

(IAE PAS, Warszawa), K.O. Kuraszkiewicz (DE FOS UW), M. Barwik, P. Bieliński, P. Dyczek, W. Godlewski, D. Ławecka, S. Rzepka, J. Żelazowski, M. Gawlikowski, J. Młynarczyk, A. Niwiński, T. Sarnowski, D. Szeląg, T. Waliszewski (IA UW, Warszawa)

\section{RÉDACTEUR THÉMATIQUE DU VOLUME \\ Barbara Lichocka}

\author{
AIDE RÉDACTION TECHNIQUE \\ Dorota Dobrzyńska, Mariusz Drzewiecki
}

REVUE DES TEXTES ANGLAIS

Jo Harper 
ÉTUDES et TRAVAUX XXX 
INSTYTUT KULTUR ŚRÓDZIEMNOMORSKICH I ORIENTALNYCH POLSKIEJ AKADEMII NAUK

\section{STUDIA i PRACE}

XXX

\section{Ro IKŚSiO \\ ESA PAN}

WARSZAWA

2017 
INSTITUT DES CULTURES MÉDITERRANÉENNES ET ORIENTALES DE L'ACADÉMIE POLONAISE DES SCIENCES

\section{ÉTUDES et TRAVAUX}

XXX

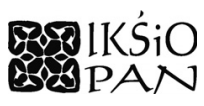

VARSOVIE

2017 
Publication scientifique financée dans le cadre du programme du Ministre de la Science et de l'Éducation Supérieure

« Programme National de Développement de l’Humanistique » pour les années 2016-2021 (projet no 3bH 150099 83)

\title{
HARODOWY PROGRAM ROZWOJU HUMANISTYKI
}

\author{
Copyright (C) \\ Instytut Kultur Śródziemnomorskich i Orientalnych PAN \\ et les Auteurs \\ Warszawa 2017
}

\author{
ISSN 2084-6762 \\ (avant $2011: 0079-3566$ ) \\ e-ISSN 2449-9579 \\ Version première en papier, imprimée en Pologne - 150 copies \\ Version électronique accessible sur \\ http://www.etudesettravaux.iksiopan.pl
}

Édition: Polskie Towarzystwo Historyczne et Wydawnictwo Neriton, Warszawa

Conception générale de couverture : J. Iwaszczuk

Photos de couverture : En haut, à gauche. Vieille Dongola 1991, S. Jakobielski

(debout à gauche), K. Pluskota (debout à droite), B. Żurawski (assis sur le camion)

et P. Wierzbicki (assis sur le camion) (de la collection de B. Żurawski)

En haut, à droite. Palmyre 1964, M. Marciniak au travail (phot. A. Dziewanowski)

Au centre. E. Laskowska-Kusztal au travail (de la collection de E. Laskowska-Kusztal)

En bas, à gauche. Tell Atrib 1962 ; de gauche : T. Biniewski, M. Marciniak, K. Kołodziejczyk,

K. Michałowski, A. Ostrasz, S. Jakobielski et S. Jasiewicz devant eux

(de la collection de IKŚSiO PAN).

En bas, à droite. Vieille Dongola 1976, S. Jakobielski nettoyant le mur (phot. M. Steinborn).

Au centre, à droite, K. Myśliwiec en train des travaux de documentation (de la collection de IKŚiO PAN) 


\section{Table des matières}

BARBARA LICHOCKA

Ergon agathon

Hartwig Altenmüller

$\mathrm{Zu}$ den Feindbildern auf den Zauberstäben des Mittleren Reiches und der Zweiten

Zwischenzeit

Nathalie Beaux

Des $m s w n s w$ de Thoutmosis III à Deir el-Bahari

Briant Bohleke, Nigel Strudwick

A Label for Opening of the Mouth Implements from the Burial of Senneferi (TT99)

and Remarks on the Ritual

Rosa Maria Bonacasa Carra, Nicola Bonacasa

Nuovi dati sugli edifici termali di Sabratha

EDWARD BROVARSKI

A Fragmentary Carrying Chair Scene in Salt Lake City, Utah

Julia Burdajewicz

Wall Painting Decoration from the North-West Church in Hippos-Sussita

of the Decapolis

Mariusz BURDAJEWICZ

From Pagan Temple to Church in Late Antiquity Palestine. A View from

Hippos-Sussita

MAREK ChlodNicki

Early Dynastic Bead Workshops at the Central Kom of Tell el-Farkha.

Patryk ChudziK, Mariusz Caban

Observations on the Architecture of the Tomb of Horhotep in Western Thebes

Krzysztof M. Cialowicz

New Discoveries at Tell el-Farkha and the Beginnings of the Egyptian State.

Amr EL-TiebI

Four Wooden New Kingdom Female Statuettes in the Egyptian Museum, Cairo 


\section{Naguib KanaWATI}

Ritual Marriage Alliances and Consolidation of Power in Middle Egypt during the Middle Kingdom

Adam Łajtar, Jolanta Mlynarczyk

A Faction Acclamation Incised on a Pithos Found Near the North-West Church at Hippos (Sussita)

Adam ŁaJTAR, Grzegorz OchaŁa

Two Private Prayers in Wall Inscriptions in the Faras Cathedral

Adam Łajtar, Anna Poludnikiewicz

Medicinal Vessels from Tell Atrib (Egypt)

JaCeK Michniewicz, Jolanta MlynarczyK

Petrographic Variability of the Fabrics of Wine Jars from Sha'ar-Ha Amakim as a Reflection of Differences in Their Provenance and Chronology

Iwona ModrzewsKa-PianetTI

Les importations d'amphores Dressel 20 en Gaule Cisalpine

Arthur SEgal

Samaria-Sebaste. Portrait of a polis in the Heart of Samaria 409

JOACHIM ŚLIWA

The Motif of a 'Blind Harper' in an Unexpected Place

MONIKA WIĘCH

Searching for the Kitchen in the Early Roman Phase of the 'Hellenistic' House at Nea Paphos (Cyprus)

Abréviations 
THE VOLUME IS PUBLISHED TO CELEBRATE

THE $60^{\text {TH }}$ ANNIVERSARY

OF THE ESTABLISHMENT OF

THE RESEARCH CENTRE FOR MEDITERRANEAN ARCHAEOLOGY POLISH ACADEMY OF SCIENCES

FOUNDED IN 1956

WHOSE MISSION IS CONTINUED BY

THE INSTITUTE OF MEDITERRANEAN AND ORIENTAL CULTURES

OF THE POLISH ACADEMY OF SCIENCES 